\title{
Edukacja wobec odwiecznych i współczesnych problemów świata - konteksty i wyzwania edukacji międzykulturowej
}

Streszczenie: Współczesny świat nękany jest wieloma problemami, które budzą niepokój o przyszłość społeczeństw żyjących w różnych częściach naszego globu. Problemy te dotyczą również społeczeństw europejskich. Dokuczliwe i pod różnymi względami szkodliwe są zachowania polityków, odżywają radykalne nurty nacjonalistyczne i szowinistyczne, nie słabną konflikty na tle religijnym, pogłębiają się różnice w warunkach życia bogatych i biednych, toksyczne jest oddziaływanie licznych środków masowej komunikacji. W tej trudnej sytuacji niewielką pomoc niesie ludziom edukacja, której powinnością jest przecież przygotowanie do życia. Powinności tej nie sposób wypełnić z powodzeniem, nie uwzględniając podstawowych problemów współczesnego świata, nie pomagając w ich zrozumieniu i poszukiwaniu rozwiązań. Szczególną rolę w tym dziele odgrywać może i powinna edukacja międzykulturowa - inspirując i promując poczynania służące przygotowaniu do godnego i zgodnego życia w dotkniętym poważnymi problemami wielokulturowym świecie.

Słowa kluczowe: podstawowe problemy współczesnego świata, edukacja, dysfunkcjonalność edukacji, edukacja międzykulturowa, wyzwania edukacyjne

Edukacja od wieków jest nadzieją na lepsze życie. Niesie nadzieję na rozwój wielu sfer ludzkiego życia - na poprawę warunków bytowych, postęp techniczny i technologiczny, lepszą ochronę zdrowia, poprawę relacji międzyludzkich i wiele innych korzystnych zmian. W dużej mierze te ogromne oczekiwania zostają spełniane. Edukacja jest jednym z ważnych czynników rozwoju jednostek i społeczeństw, rozwoju gospodarczego, odkryć naukowych, rozwoju kultury, poprawy jakości życia.

Jednak oddziaływania edukacji okazują się wciąż dalekie od spodziewanych przez optymistów. Oświeceniowe wizje lepszych ludzi i ich świata - ukształtowanych dzięki oświacie - pozostają pięknym marzeniem. Upo- 
wszechnienie oświaty nie przyniosło rezultatów, o których można mówić, że zdecydowanie zmieniły świat na lepsze. Pomimo wykształcenia - ludzie wciąż czynią wiele zła, nierzadko wykorzystując przy tym wiedzę, zdobyte umiejętności, wygenerowane w toku działalności naukowej rozmaite środki. Trwają wojny, nie zanikają rozmaite formy wyzysku, nie gaśnie nienawiść, tragiczne w skutkach konflikty na tle ideologicznym, religijnym, kulturowym. Znaczna część ludzkości żyje w nędzy i poniżeniu. Świat ludzi nawet bardzo dobrze wykształconych zaniedbuje lub dość leniwie podejmuje działania, żeby życie innych ludzi stawało się lepsze. Edukacja nie jest siłą sprawczą radykalnie poprawiającą sytuację życiową wciąż dużej części ludności świata. Nadal przecież pozostaje nadzieją, szansą, jedną z dróg czynienia ludzi i ich świata lepszymi, bardziej przyjaznymi.

Poczucie nader ograniczonego lub nawet braku sprawstwa bywa przyczyną licznych frustracji i kryzysów dotykających nauczycieli i społeczności zajmujące się pedagogiką jako dyscypliną nauki. I praktycy, i teoretycy często czują się bezradni, rezygnują z prób oddziaływania na innych ludzi, w bardziej lub mniej jawny sposób godzą się na świat z jego złymi stronami życia. Wielu nauczycieli i pedagogów jednak podejmuje swoją misję i stara się sprzyjać ludziom w ich zmaganiach, aby stać się człowiekiem w najlepszym znaczeniu tego słowa. We wspólnym dążeniu do tego celu pomocna może okazać się wiedza o rodzajach i skali problemów, z którymi zderza się działalność edukacyjna. Wiedza ta zwiększa szanse na racjonalne funkcjonowanie i poszukiwanie sposobów przezwyciężania trudności, także radzenia sobie z własnymi rozterkami, wątpliwościami, wypaleniem zawodowym, zagrożeniem rezygnacją. Próbę określenia podstawowych problemów, które ograniczają lub wykluczają pozytywny program i pozytywne skutki edukacji, przedstawiam w tym tekście. W szczególnym zakresie odnosi się to również do tego obszaru edukacji, który określamy jako edukację międzykulturową.

Współczesna pedagogika - przynajmniej w jej dominującym nurcie na naszym kontynencie - mocno akcentuje sprawy podmiotowości, indywidualnego traktowania podmiotów edukacji, unikatowości procesów edukacyjnych i rozwoju poszczególnych jednostek. To ważne ujęcie zagadnień edukacji - szczególnie po latach podejścia „kolektywnego”, zbiorowego, masowego itp., jakie wcześniej panowały w pedagogice i w oświacie wielu państw europejskich ${ }^{1}$. Problemy edukacji nie ograniczają się jednak do skali przypad-

1 Traktują o tym zarówno prace z pedagogiki ogólnej, podręczniki pedagogiki, jak i opracowania z historii wychowania wydane po roku 1989. 
ków indywidualnych. Edukacja pozostawała i pozostaje w silnych - czasem krępujących ją - związkach z innymi dziedzinami życia. Wynikające z tego problemy wykraczają poza skalę indywidualną, mają wymiar społeczny o zasięgu nierzadko globalnym. I one właśnie w dużej mierze wyznaczają szanse edukacji. Niektóre z tych problemów wydają się oczywiste, znane, ale w tym poczuciu oczywistości gubi się wątki ważne w rozumieniu i wypełnianiu misji edukacji. Z tego powodu warto im poświęcić uwagę i przywołać sprawy, które powinny stanowić o przesłaniach edukacyjnych w ogóle, a w świecie nękanym wielkimi problemami w szczególności.

Rozważania o edukacji w kontekście problemów współczesnego świata wydają się bardzo ważne dla pedagogów zaangażowanych w lansowanie idei i prowadzenie praktycznych działań obejmowanych nazwą edukacji międzykulturowej. Głoszony ostatnio kryzys wielokulturowości w Europie, wybuchające konflikty narodowościowe i religijne, odradzanie się nacjonalizmów i szowinizmów mogą osłabiać przekonanie o sensie edukacji międzykulturowej, osłabiać aktywność edukacyjną. Zdarzają się - dobrze, że nieliczne - przykłady świadczące o pokusie powrotu do któregoś z modeli edukacji wielokulturowej, sprzyjającej zamykaniu się w ramach odrębnych grup narodowych, etnicznych, kulturowych czy religijnych ${ }^{2}$. Być może jest to swoisty odruch samoobrony wobec ponownego nasilania się nacjonalizmów, braku tolerancji, trudności pojawiających się w życiu społeczeństw Unii Europejskiej, a może to wspomniane już zachwianie wiary w skuteczność edukacji międzykulturowej. Takie reakcje nie wróżą dobrych rozwiązań. Dlatego, jak sądzę, trzeba przypominać kwestie, które są istotne w kształtowaniu ideologii i praktyki edukacyjnej sprzyjającej przygotowaniu ludzi do godnego, wspólnego, kooperacyjnego, szczęśliwego życia w warunkach wielokulturowości ${ }^{3}$.

Kilka problemów współczesnego świata ma odwieczną, złą tradycję. Wbrew tej tradycji trzeba konsekwentnie tworzyć nową przestrzeń eduka-

2 Por. np. T. Lewowicki: W poszukiwaniu modelu edukacji międzykulturowej. W: T. Lewowicki, E. Ogrodzka-Mazur, A. Szczurek-Boruta (red.): Edukacja międzykulturowa w Polsce i na świecie. Katowice 2000, UŚ, s. 21-35; T. Lewowicki, E. Ogrodzka-Mazur, A. Szczurek-Boruta (red.): Edukacja międzykulturowa - dokonania, problemy, perspektywy. Cieszyn - Warszawa - Toruń 2011, Wydział Etnologii i Nauk o Edukacji Uniwersytetu Śląskiego, Wyższa Szkoła Pedagogiczna ZNP w Warszawie, Wydawnictwo Adam Marszałek; T. Lewowicki: Edukacja międzykulturowa - bilans otwarcia 2012. „Edukacja Międzykulturowa” 2012, nr 1, s. 15-46.

3 Tamże. 
cyjną, która ma przyczyniać się do powstawania nowej tradycji - wolnej od historycznych obciążeń. Inne problemy pojawiają się w wyniku zmian cywilizacyjnych - w tym, paradoksalnie, ułatwień w komunikacji między ludźmi, niemal nieograniczonemu przepływowi informacji. Przywołajmy niektóre odwieczne i także wybrane nowe problemy. Edukacja jest w nie mocno uwikłana.

\section{Trudne dzieje i toksyczna polityka}

Typowy przekaz dziejów ludzkości w dużej części wypełniony bywa listą tragicznych wydarzeń, konfliktów, wojen. Od tysiącleci ludzie przejawiali agresję, stosowali przemoc. Dawne walki często dyktowane były brakiem zaspokojenia podstawowych potrzeb - brakiem żywności, niedostatkiem siły roboczej. Z czasem motywami wojen stała się chęć opanowania coraz rozleglejszych terytoriów oraz podporządkowania ich mieszkańców. Motywem była chęć wzbogacenia się, coraz częściej też pokusa zyskania sławy, złe ambicje czy chorobliwa żądza władzy. Zazwyczaj spokojne życie ludności przerywane było częstymi wojnami wywoływanymi przez własne elity władzy, władców albo przez władców ościennych ludów i terytoriów. W ustnym, a potem pisemnym przekazie dziejów dominowały opisy dokonań własnej grupy i opisy złych sąsiadów, okrutnych Obcych. W edukacji do dzisiaj nie brakuje takiego utrwalania dziejów. Pamięć złych doświadczeń, a jednocześnie zazwyczaj wypaczonego obrazu historii, kształtuje postawy kolejnych pokoleń. Nawet współcześnie, w państwach od dziesięcioleci pielęgnujących pokój, w edukacyjnym przekazie silniej akcentowane są historyczne wydarzenia militarne, konflikty zbrojne - niż osiągnięcia w różnych dziedzinach życia. Spostrzegany świat ludzi nieustannie zawiera podziały na My i Oni, Nasi i Obcy - przeważnie dobrzy, mężni, szlachetni Nasi i źli, zaborczy, prymitywni Obcy. Bagaż złych doświadczeń wciąż wyznacza myślenie o ludziach. O naukach płynących z przeszłości, oczywiście, trzeba pamiętać - rzecz w tym, że obraz przeszłości wydaje się przesłaniać obraz współczesności. W edukacji wskazane wydaje się bardziej rozumne potraktowanie relacji między przeszłością a współczesnością (i przewidywaną, możliwą i upragnioną przyszłością).

Wynaturzony, w dużym stopniu zafałszowany obraz świata powstaje od stuleci m.in. po wpływem polityki, a ściślej - uprawiających ją ludzi. Politykę traktuje się przede wszystkim jako obszar i sposób zdobywania i utrzyma- 
nia władzy ${ }^{4}$. Rzadziej widzi się w niej sferę działalności, w ramach której ogólnie rzecz ujmując - wyznacza się cele społecznej działalności i troszczy o zapewnienie warunków umożliwiających osiąganie tych celów ${ }^{5}$. Dodajmy - celów, które uwzględniają potrzeby i dobro obywateli, a nie głównie rządzących elit, partii czy jakichś innych wybranych grup społecznych. Prawie nie przyjmuje się do wiadomości i nie przypomina, że - jak określono to kiedyś - polityka powinna służyć temu, aby ludzie byli szczęśliwi. Instrumentalne traktowanie polityki odzwierciedla się również w instrumentalnym traktowaniu edukacji. Wiadomo o tym powszechnie, ale trudno uznać, że podejmowane są wysiłki, aby edukację uwolnić od (przynajmniej nadmiernego) wpływu polityki. Pozostaje wierzyć, że kształtujące się (niestety, bardzo powoli i z kłopotami) społeczeństwo obywatelskie doprowadzi - przy udziale ekspertów - do wyraźnego uwolnienia edukacji od doraźnych interesów polityków. Związki edukacji z polityką (raczej nieuniknione) powinny dotyczyć przede wszystkim spraw polityki społecznej, strategii rozwoju społeczeństwa i państwa, nakładów na oświatę i naukę.

Uwolniona - lub ostrożniej: uwalniana - od polityki (szczególnie doraźnej polityki partyjnej) edukacja powinna zwracać uwagę na fałszywe fasady ideologii partyjnych, na hipokryzję świata polityków. Powinna uczyć krytycznego podejścia do polityki i polityków oraz przygotowywać do racjonalnego, odpowiedzialnego uczestnictwa w różnych formach demokracji, przygotowywać (od wczesnych lat nauki w szkole) do współtworzenia społeczeństwa obywatelskiego.

Powinnością edukacji, a w jej ramach edukacji międzykulturowej jako ważnego obszaru ogólnej edukacji, jest wskazywanie fałszu w obrazie dziejów, stereotypów i wynaturzonych przekazów dotyczących ludzi innych narodowości, religii czy wyznań, kultur. W zamian edukacja proponować powinna możliwie obiektywny, ale nade wszystko pozytywny program wiedzy o Innych, różnych kulturach, a jednocześnie o wspólnych wartościach, możliwościach wspólnych pożytecznych przedsięwzięć, szansach i pożytkach

4 Por. np. W. Okoń: Nowy stownik pedagogiczny. b.r.w., „Żak”; Encyklopedia popularna PWN. Warszawa 1982, PWN, s. 602.

5 Por. np. M. Chmaj, W. Sokół (red.): Mała encyklopedia wiedzy politycznej. Toruń 1996, Wydawnictwo Adam Marszałek; W. Okoń: Nowy stownik pedagogiczny. cyt. wyd. Piszę o tych sprawach szerzej w tekście T. Lewowicki: Polityka oświatowa - od demona przeszłości, przez chaos okresu przemian ustrojowych - ku nowej polityce oświatowej. W: R. Kwiecińska, S. Kowal (red.): Edukacyjne drogi i bezdroża. Kraków 2002, AP. 
współpracy. Bagaż złych doświadczeń z przeszłości pora zastępować wiedzą, doświadczeniami i przesłaniami, zwiększającymi szanse lepszego życia we wspólnym wielokulturowym świecie.

\section{Religie jako pola konfliktów}

Religie były i są ważnymi obszarami życia ludzi. W przesłaniach różnych religii znajdują się wartości i sprawy znajdujące niemal powszechną aprobatę. Znane wielkie religie - w tym chrześcijaństwo - głoszą nakazy czynienia dobra, miłości do innych ludzi. Niektóre religie uznają tego samego Boga. I jednocześnie na tle religijnym prowadzone były i nadal wybuchają wojny religijne, konflikty zbrojne, zdarzają się akty przemocy, ostatnio groźny stał się terroryzm.

Nierzadko sprawy religii kojarzone są z polityką. Politycy wykorzystują kwestie religijne w potyczkach o władzę, przedstawiciele różnych Kościołów, wyznawcy różnych religii sięgają po oręż polityczny, aby osiągnąć swoje cele, zwiększyć lub umocnić swoje wpływy w życiu społecznym. W niektórych pozaeuropejskich regionach świata różnice religijne są wciąż powodem lub pretekstem czystek etnicznych, przemocy, lokalnych wojen.

Duża część religii ma swoje instytucjonalne formy zorganizowania. Od starożytności ważni przedstawiciele Kościołów czy innych społeczności religijnych ubiegali się o władzę i często sprawowali władzę - konkurując z władzą świecką. Utrwalona tradycja nadal zachęca do sprawowania „rządu dusz", zabiegania o wpływy i głoszenie, że wyznawana religia i czczony Bóg są jedynymi prawdziwymi. Nawet Kościoły chrześcijańskie - jak wydaje się, ostatnio otwarte na idee ekumenizmu ${ }^{6}$ - wciąż pozostają wzajemnie odległe,

6 Por. np. J. Budniak: Miejsce dialogu ekumenicznego w środowisku wielowyznaniowym Ślaska Cieszyńskiego. W: T. Lewowicki, A. Różańska, U. Klajmon-Lech (red.): Religia i edukacja międzykulturowa. Cieszyn - Warszawa - Toruń 2012, Wydział Etnologii i Nauk o Edukacji Uniwersytetu Śląskiego, Wyższa Szkoła Pedagogiczna ZNP w Warszawie, Stowarzyszenie Wspierania Edukacji Międzykulturowej, Wydawnictwo Adam Marszałek; M. Walancik, A. Niewiara: Międzykulturowość z perspektywy pontyfikatu Jana Pawta II. W: T. Lewowicki, A. Różańska, U. Klajmon-Lech (red.): Religia i edukacja międzykulturowa. Cieszyn - Warszawa - Torun 2012, Wydział Etnologii i Nauk o Edukacji Uniwersytetu Śląskiego, Wyższa Szkoła Pedagogiczna ZNP w Warszawie, Stowarzyszenie Wspierania Edukacji Międzykulturowej, Wydawnictwo Adam Marszałek; J. Górecki: Ekumenizm w nauczaniu pastoralnym Jana Pawła II. W: J. Górecki (red.): Jan Pawet II - pasterz i pielgrzym. Katowice 2009, UŚ. 
a ekumenizm - traktowany przez wielu wiernych jako dążenie do jedności chrześcijan i ich Kościołów - pojmowany i uprawiany jest przez niektórych teologów głównie jako forma dialogu, a nie starań o pojednanie, a tym bardziej o jedność. To niewątpliwie szczere postawienie sprawy, lecz podważające nadzieje na coś więcej niż dialog dla samego dialogu. To delikatna sfera życia społecznego, słabo poddająca się zmianom. Pocieszające jest to, że w codziennych kontaktach wielu ludzi - jak się wydaje - coraz mniej uwagi przywiązuje do różnic związanych z podziałem Kościołów chrześcijańskich.

Edukacja w różnych państwach często podtrzymuje i wzmacnia te podziały - niosąc przekaz o prawdziwości religii wyznawanej w danym państwie czy religii dominującej na danym terenie. Pomijana jest lub bardzo nikła wiedza o innych religiach, bardziej lub mniej zdawkowo przywoływane sprawy tolerancji, praw ludzi do wyznawania wybranej religii, wolności światopoglądowej. Edukacja przeważnie włącza się do wsparcia dominującego nurtu wychowania religijnego w rodzinach i w Kościołach. To kolejne pole podziału na My i Oni, Nasi i Obcy. To stałe zarzewie konfliktów, w których podziały religijne czy wyznaniowe można wykorzystać jako pretekst do podjęcia przemocy. Współcześnie niepokój - jak wydaje się - budzi niebezpieczeństwo konfliktu cywilizacji ${ }^{7}$, powiązanych z - jak wiadomo - różnymi religiami. Niektórzy wieszczą konflikt na tle religijnym i społecznym między chrześcijaństwem i islamem.

W wielokulturowym świecie edukacja ma do spełnienia nie tylko podtrzymywanie własnej czy dominującej tradycji religijnej, ale w znacznym zakresie niesienie wiedzy o innych religiach, szerzenie kultury religijnej, uczenie krytycznego podejścia do kwestii religijnych i poszukiwania wartości i spraw, które mają walor ogólnoludzki, mają wymiar uniwersalny ${ }^{8}$. I chociaż takie spostrzeganie roli edukacji wciąż nie cieszy się powszechnym uznaniem, a edukacja religijna należy do kwestii nader drażliwych i budzących różne emocje, to trudno liczyć na pokojowe i kooperacyjne relacje między ludźmi

7 Por. np. S. P. Huntington: The Clash of Civilizations and Remarking of World Order (praca z roku 1996), wydanie polskie: Zderzenie cywilizacji i nowy ksztatt tadu światowego. Warszawa 1997, Muza.

8 Por. np. T. Lewowicki, A. Różańska, U. Klajmon-Lech (red.): Kwestie wyznaniowe w społecznościach wielokulturowych. Cieszyn 2002, UŚ - Filia w Cieszynie; A. Różańska: Działalność edukacyjna Ślaskiego Kościoła Ewangelickiego Augsburskiego Wyznania na Zaolziu. Cieszyn 2002, ŚKEAW; T. Lewowicki, A. Różańska, U. Klajmon-Lech (red.): Religia i edukacja międzykulturowa. cyt. wyd. 
różnych kultur i religii bez pozytywnego oddziaływania właśnie tak podejmowanej edukacji.

\section{Falowanie nastrojów prointegracyjnych i dezintegracyjnych}

Osobliwością życia społecznego jest zmienność postaw wobec kwestii integracji vs. dezintegracji społeczeństw i państw. Po wiekach tworzenia imperiów na drodze zaborów i rozpadu tych imperiów współczesne państwa i społeczeństwa mają możliwości (przynajmniej w jakimś stopniu) współdecydowania o jednoczeniu się w duże organizmy państwowe lub nawet ponadpaństwowe, albo przeciwnie - o oddzieleniu się, usamodzielnieniu. $\mathrm{Na}$ gruncie europejskim - po kolejnych wojnach dotykających kilka kontynentów - ukształtowały się liczne państwa, w których zazwyczaj dominowała jedna społeczność narodowa, ale obywatelami tych państw były i są także społeczności innych narodowości niż ta dominująca (nazywana większościową). Po drugiej wojnie światowej - jak pamiętamy - trwało imperium radzieckie, utworzone siłą po rewolucji 1917 roku i obejmujące liczne narody i terytoria kilkunastu byłych państw, a ponadto powstał raczej sztuczny organizm państwowy - Jugosławia - także obejmujący różne narody i terytoria należące wcześniej do różnych państw. Wiele z tych siłą zjednoczonych narodów pragnęło samodzielności, lecz przez długi czas było to niemożliwe do spełnienia. Usamodzielnienie następowało dopiero w latach 90. ubiegłego wieku, kiedy po rozwiązaniu ZSRR narody mogły odtworzyć lub stworzyć niezależne państwa.

W Europie Zachodniej - po traumie wojennej - stosunkowo szybko ujawniły się tendencje do integracji najpierw gospodarek i handlu, a początkiem stała się Wspólnota Węgla i Stali, następnie z biegiem lat dostrzeżono pozytywne strony integracji politycznej, a także militarnej. W odróżnieniu od państw tzw. bloku socjalistycznego - państwa zachodnioeuropejskie dążyły do integracji wielu dziedzin życia i integracji państw. Wizjonerzy i mądrzy politycy tamtych czasów - m.in. Robert Schuman, Konrad Adenauer, Alcide De Gasperi, Jean Monnet, Paul-Henri Spaak, Altiero Spinelli dali impuls do powstania Unii Europejskiej.

Po radykalnych zmianach społeczno-politycznych z początku ostatniej dekady ubiegłego wieku liczba państw pragnących integracji europejskiej znacząco wzrosła. Dzisiaj, jak wiemy, UE obejmuje już 27 państw europejskich, 
a współpraca handlowa i gospodarcza oraz wolny przepływ ludzi, towarów i kapitału obejmuje jeszcze więcej państw. Integracja przynosi nieocenione korzyści - pokojowe współistnienie, kooperację, gwarancje praw człowieka, swobodę migracji, wolny rynek, wspólne standardy dotyczące różnych dziedzin życia. Nowe państwa współtworzące UE - w tym Polska - korzystają ze znacznego dofinansowania rozmaitych obszarów życia społecznego i gospodarki. Wszystkie państwa korzystają z funkcjonowania wspólnej przestrzeni gospodarczej, finansowej, kulturalnej. Model integracyjny poddawany jest jednak krytyce przez polityków i części społeczeństw nastawionych niechętnie do struktur ponadnarodowych i ponadpaństwowych. Konserwatyzm, ksenofobia, patriotyzm kojarzony często z nacjonalizmem i szowinizmem skłaniają do podważenia integracji europejskiej. Nie przeszkadza to w formułowaniu rozmaitych roszczeń i korzystaniu z pomocy Unii Europejskiej. Gra polityczna, hipokryzja, trwanie w dawnych lękach tworzą dziwną mieszankę chęci i niechęci do integracji. Większość polityków i społeczeństw dostrzega szanse, jakie niesie integracja i wydaje się dążyć do tego, aby ten niezwykły eksperyment, jakim stała się Unia Europejska, powiódł się - ku pożytkowi wszystkich uczestników.

Kryzys finansów i jego pochodne - dotykające USA i Europę - spowodowały lawinę żądań naruszających integrację. Znane są przyczyny kryzysów, znane zachowania polityków i dużych części społeczeństw. Problemy finansów i standardu życia wzmagają tendencję dezintegracyjną. Tendencji tej poddają się także różne społeczności w państwach wielonarodowych lub wieloetnicznych. Rzecz dotyczy już nie tyle oderwania od Unii Europejskiej, ile usamodzielnienia się i wyodrębnienia ze struktur państwa, w których te społeczności żyją. Bogaci Katalończycy chcą usamodzielnić się i odłączyć od Hiszpanii, ale jednocześnie pozostać w Unii Europejskiej. Samodzielność jest dążeniem części Basków. Szkocja zgłasza chęć usamodzielnienia się i odłączenia od Wielkiej Brytanii. I w tym przypadku zamożniejsza (niż inne państwa Wielkiej Brytanii) Szkocja nie chce solidarnie dzielić się swoimi dobrami z innymi. Ruchy separatystyczne, dążenia do secesji są żywe w Belgii, gdzie Flamandowie i Walonowie chcieliby tworzyć odrębne organizmy państwowe. Fala separatyzmów nasila się. Względy ekonomiczne, czasem złudne przekonanie o niezwykłych walorach samodzielności, odradzające się nacjonalizmy, przywoływana pamięć złych doświadczeń kształtują klimat zachęcający do dezintegracji. Często są to zachowania nieracjonalne, oderwane od szacunku szans rozwojowych ewentualnych nowych państw. Emocje wywołane 
przejściowymi trudnościami przesłaniają dokonania i szanse zintegrowanej Europy. Zamiast wspólnego działania na rzecz przezwyciężenia trudności, górę biorą partykularyzmy, uśpione (a teraz obudzone) ambicje, wyobrażenia o przyszłości oderwane od realiów i potrzeb oraz szans rozwojowych europejskich społeczeństw.

Przypomnienie tych znanych spraw ilustruje zmienność nastrojów społecznych, nieumiejętność perspektywicznego widzenia warunków i szans rozwoju, niedocenianie osiągnięć integracji. Stosunkowo szybkie i poważne dokonania Unii - znacznie poprawiające jakość życia obywateli państw stowarzyszonych w UE - są nader lekko zbywane, podważane. Wahadło nastrojów przesunęło się od wielkiego optymizmu do pesymizmu i zachowań destrukcyjnych. I w tym przypadku jest ważne miejsce dla edukacji, która powinna pokazywać przebieg zachowań społecznych, pomagać w analizie znanych rezultatów i przygotowywać do racjonalnego przewidywania skutków różnych scenariuszy wydarzeń, pomagać w dokonywaniu własnych, racjonalnych, odpowiedzialnych i prorozwojowych wyborów. Jak dotąd, nie wydaje się, żeby edukacja z powodzeniem wypełniała te powinności. W chaosie poglądów, jazgocie politycznych kłótni, zagubieniu wielu ludzi - potrzebny i wskazany jest udział edukacji w całościowym i rozważnym prezentowaniu jakże ważnych spraw niezwykłego projektu europejskiej integracji.

\section{Narastający konflikt bogatych i biednych}

Skoncentrowani na najbliższym otoczeniu, cieszymy się - pomimo kłopotów - relatywnie wysokim standardem życia i pokojem, możliwością korzystania z praw człowieka - zazwyczaj zdawkowo i biernie przyjmujemy liczne informacje o narastającym rozwarstwieniu dochodów, zróżnicowaniu warunków życia i konfliktach powodowanych nędzą w wielu krajach świata. Zróżnicowanie to coraz silniej występuje w państwach bogatych, ale szczególnie drastyczne jest w zderzeniu społeczeństw bogatych i biednych. Znaczna część ludności Afryki, Ameryki Południowej i Azji żyje w skrajnej nędzy, w głodzie, bez dostępu do wody i elektryczności, bez opieki zdrowotnej. Ludzi biednych - na szczęście żyjących w lepszych warunkach niż te, w których egzystują mieszkańcy innych regionów świata - nie brak też w Europie.

To rozwarstwienie, nędza milionów ludzi, poczucie krzywdy i narastający bunt są problemem, który razi poczucie sprawiedliwości i który może zagrozić światu. W połączeniu z prowokacjami politycznymi i ruchami spo- 
łecznymi związanymi z religiami narodzić się może konflikt trudny do opanowania, niosący wielką siłę niszczącą, burzący liczne instytucje i dotykający społeczeństwa i państwa. Wieki wyzysku, przemocy, niewoli pogłębiły biedę - najogólniej mówiąc - społeczeństw Południa. Dzisiaj coraz wyraźniej ujawnia się - tłumiony dawniej siłą - konflikt. Bogaci, wzbogaceni bardzo często kosztem biednych, nie kwapią się do niesienia pomocy, w niewielkim stopniu chcą dzielić się swoim bogactwem. Idea solidarności, pomocy biednym, porusza niewielką część zamożnych społeczeństw. Typowymi zjawiskami są obojętność, znieczulica, samousprawiedliwienie, że niewiele da się zrobić, żeby poprawić los biednych, wykluczonych. Postawy takie można i powinno się przezwyciężać $\mathrm{w}$ różnych formach edukacji. Edukacja może kształtować wrażliwość na problemy ludzi i postawy pomocowe - zarówno wobec osób z najbliższego otoczenia, jak i tych z dalekich stron, dla których drobna moneta jest środkiem na przeżycie kolejnego dnia. Dzięki edukacji można spowodować ograniczenie marnotrawstwa żywności, wspierać programy pomocowe dla społeczności dotkniętych biedą, a w przyszłości może doprowadzić do bardziej sprawiedliwej dystrybucji dóbr. Nadzieja w poruszeniu sumień i serc, ale także umysłów ludzi. Wątpliwe, czy zdobędą się na to politycy, elity władzy, rekiny finansjery. Nadzieją pozostaje wychowanie, kształtowanie świata wartości i postaw. W tym dziele mogą i powinni zjednoczyć wysiłki m.in. Kościoły, pozarządowe organizacje charytatywne, ale edukacji - oddziałującej bezpośrednio na miliony ludzi - przypada rola szczególna. Istotne wydaje się przy tym kształtowanie klimatu społecznego wywierającego presję na udział bogatych podmiotów życia społecznego, finansowego czy gospodarczego $\mathrm{w}$ działaniach na rzecz poprawy warunków życia ludzi biednych.

\section{Destrukcyjne oddziaływanie mass mediów i języka sfery publicznej}

Niezwykłym osiągnięciem współczesnej cywilizacji są media umożliwiające niemal nieograniczoną komunikację, przepływ informacji, a także gromadzenie i opracowywanie tych informacji. Media te pełnią wiele pożytecznych funkcji - w tym funkcje edukacyjne. Jednak ich oddziaływania nie da się ocenić tylko pozytywnie. Komercjalizacja środków masowego przekazu, swoiste fetysze wskaźników oglądalności programów telewizyjnych i wskaźników korzystania z innych mediów doprowadziły do przesadnych starań o epato- 
wanie odbiorców sensacjami, katastrofami, wydarzeniami patologicznymi. Pożywką mediów stały się żenujące kłótnie polityków, przejawy nienawiści, głupota. Przekazy zawierające wartościowe treści edukacyjne są dzisiaj marginesem, drobną częścią programów telewizji, radia, coraz mniejszą częścią tekstów drukowanych w czasopismach. Szacuje się, że w Europie programy edukacyjne czy zawierające treści poznawcze zajmują średnio około $25 \%$ czasu antenowego, przy czym np. w Niemczech i Holandii jest to ponad 30\%, a w innych państwach często znacznie mniej ${ }^{9}$. Dotyczy to zarówno mediów komercyjnych, jak i publicznych, których powinnością jest pełnienie misji edukacyjnej i kulturalnej. Dominują przekazy utrwalające stereotypy, budzące złe emocje, wywołujące stres. Obraz świata kreowany przez media nader często prowadzić może do wniosku, że ludzie są źli, kłótliwi, leniwi. Kształtowane są postawy pesymizmu, rezygnacji, niezadowolenia, rodzą się obawy, strach. U niektórych ludzi wyzwala się agresja, przejawy patologii podobne do tych oglądanych na ekranach telewizyjnych czy opisywanych w innych mediach.

Integralną częścią wspomnianych przekazów jest język. W sferze publicznej dominuje język prymitywny, nacechowany wrogością, promujący myślenie i zachowania destrukcyjne. Za fasadą pięknych, górnolotnych deklaracji panuje język walki, oskarżeń, pomówień. Tak opisywany i doświadczany za pomocą języka świat ${ }^{10}$ staje się obcy i wrogi. Za pomocą języka w pewnej mierze tworzymy świat, także relacji między ludźmi. W przypadku języka sfery publicznej uzasadniona wydaje się opinia, że język ten oddziałuje destrukcyjnie - stał się narzędziem dezintegracji społecznej, środkiem dekonstrukcji państwa demokratycznego, tworzywem wizji patologicznego świata, środkiem niszczenia świata wartości i autorytetów ${ }^{11}$.

Oddziaływanie środków masowej komunikacji i języka sfery publicznej ma niekorzystny wpływ na rozwój i wychowanie dzieci i młodzieży, a także na spostrzeganie świata i postawy osób korzystających z mediów - bez względu na wiek. Negatywne oddziaływania niesie szeroko pojmowana cy-

9 Por.: P. J. Sauch: Suczastna oswita. Portret bez prikras. Żitomir 2012, Wid. ŻDU im. I. Franka, s. 69.

10 J. Bartmiński (red.): Językowy obraz świata. Lublin 1990, UMCS; H. G. Gadamer: Prawda i metoda. Kraków 1993, Inter Esse.

11 T. Lewowicki: O szkodliwości wspótczesnego języka sfery publicznej. W: T. Lewowicki (red.): „Gorace” problemy edukacji w Polsce. Warszawa 2007, Komitet Nauk Pedagogicznych PAN, Wyższa Szkoła Pedagogiczna ZNP w Warszawie. 
berprzestrzeń ${ }^{12}$. Wobec wszystkich tych zjawisk powinny być podjęte odpowiednie działania edukacyjne - zapobiegające zagrożeniom, przygotowujące do selekcji treści, ich krytycznego odbioru i właściwego korzystania.

\section{Wyzwania wobec edukacji międzykulturowej}

Przytoczona lista problemów - a jest to przecież tylko subiektywny wybór dokonany spośród wielu problemów nękających współczesny świat - rzeczywiście, o czym wspomniałem we wcześniejszym fragmencie tekstu, może przytłaczać, zniechęcać do działań, rodzić rezygnację. Intencja uświadomienia czy podkreślenia znaczenia i skali trudności jest jednak inna. Do zmierzenia się z problemami prowadzić może i powinna edukacja, która pomoże dostrzec i zrozumieć te problemy, określić postawy ludzi oraz znaleźć drogi prowadzące do rozwiązań pozytywnych, a wreszcie podjąć działania zmierzające do pokonania trudności i zapobiegania nowym zarzewiom konfliktów.

Edukacja powinność tę spełnia w niewielkim zakresie. Spory o treści kształcenia dotyczą przeważnie zupełnie innych spraw niż te przywołane - istotne dla społeczeństw i wyznaczające szanse na przyszłość. Edukacja szkolna stała się powierzchowna, fragmentaryczna, ograniczona w warstwie przekazu fundamentalnych wartości i norm życia społecznego. Zjawisko obniżenia jakości kształcenia i wychowania dotyka wiele społeczeństw. Ludzie - pomimo upowszechnienia edukacji, a częściowo w konsekwencji słabo przygotowanego i niezbyt kontrolowanego umasowienia coraz wyższych poziomów edukacji (procesu, który budzi nadzieje, ale który wydaje się odbywać bez większej troski o poziom kształcenia i wychowania) - wydają się coraz bardziej zagubieni, słabo rozumieją otaczający świat, nawet ten najbliższy świat lokalny, regionalny, własnego państwa. Zamiast uczestniczyć w demokratycznych procesach świadomego, racjonalnego i odpowiedzialnego kształtowania życia społecznego poddają się syreniemu śpiewowi polityków, rozmaitym odmianom indoktrynacji i emocjom, albo poddają się swoistej alienacji, oderwaniu czy wyobcowaniu z uczestnictwa w aktywności obywatelskiej dającej szanse na zmianę świata polityki (tej w skali lokalnej i tej w skali ponadlokalnej). Takim postawom nie zapobiega, a nierzadko sprzyja edukacja. Młodzi ludzie poznają złe wzory już w szkole, potem w innych środowiskach.

12 T. Lewowicki, B. Siemieniecki (red.): Cyberprzestrzeń i edukacja. Toruń 2012, Wydawnictwo Adam Marszałek. 
Osobliwością jest to, że edukacja szkolna obejmuje prawie wszystkie dzieci i - do pewnego wieku - młodzież. W naszym kraju jest to jedyna instytucja, która pozostaje obowiązkowa. W założeniu powinna przygotowywać do życia. W rzeczywistości bardzo zdawkowo traktuje problemy, które odgrywają i będą odgrywać dużą rolę w kształtowaniu przyszłości społeczeństw, a w nich poszczególnych ludzi. Powraca więc w nowej odsłonie znany problem dysfunkcjonalności szkoły ${ }^{13}$. Dodajmy - dysfunkcjonalności w warunkach niezwykle szybkich i radykalnych zmian w świecie, a zatem w czasie, kiedy rola tej obowiązkowej i mającej służyć ludziom instytucji powinna być bardzo znacząca, wspierająca, pomocna.

Wszystko to skłania do podjęcia starań o to, aby szkoła (szerzej - edukacja) znacznie lepiej wypełniała przypisywane jej funkcje społeczne. W zakresie zagadnień, o których mowa jest w tym tekście, potrzebne są takie zmiany w treściach kształcenia i metodach pracy, które pomogą poznać i zrozumieć problemy współczesnego świata, a także podejmować działania prowadzące do rozwiązywania problemów. Potrzebne są starania o to, aby uczestnicy procesów edukacyjnych potrafili krytycznie analizować i oceniać poczynania polityków, aby umieli i chcieli rozsądnie korzystać z mediów masowej komunikacji, żeby poznawali świat wielu kultur oraz potrafili godnie i zgodnie żyć w tym świecie, żeby ich wybory życiowe dokonywane były mądrze i z uwzględnieniem przesłań płynących z katalogu uniwersalnych wartości i norm życia społecznego.

To heroiczne, trudne do wykonania, ale konieczne zadania edukacji. Właśnie w edukacji pozostaje pokładać nadzieje w sytuacji, gdy trudno liczyć na to, że korzystne zmiany nastąpią dzięki politykom, dysponentom środków masowej komunikacji czy innym znaczącym grupom społecznym. Pomimo wielu trudnych doświadczeń i niepowodzeń - należy mieć wiarę, że edukacja może stać się i stanie się ważnym czynnikiem zmian.

Oczekiwania wobec edukacji w szczególny sposób odnieść należy do edukacji międzykulturowej. Właśnie na gruncie edukacji międzykulturowej znaleźć można wiele przykładów wrażliwości na problemy współczesnego świata, wiele też jest przykładów edukacyjnych przedsięwzięć, które dobrze służą jego poznawaniu i rozumieniu ${ }^{14}$. Społeczność zajmująca się edukacją międzykulturową ma już spore dokonania w przygotowywaniu nauczycie-

13 Por. np. T. Lewowicki: Przemiany oświaty. cyt. wyd.

14 Liczne przykłady znajdują się m.in. w publikacjach ukazujących się w serii Edukacja Międzykulturowa, a także w innych pracach z zakresu edukacji międzykulturowej. 
li do podejmowania przywoływanych tu problemów. Wykorzystywane są $\mathrm{w}$ polityce edukacyjnej różne programy i metody sprawdzone w promowaniu wiedzy o wielokulturowym świecie i problemach tego świata. Przypomnieć należy, że w ujęciu właściwym rodzimej edukacji międzykulturowej świat wielokulturowy pojmowany jest w sposób bliski bachtinowskiemu (Michaiła Bachtina) rozumieniu pogranicza kultur, a więc styku i zderzeniu kultur nie tylko między różnymi narodami czy grupami etnicznymi, ale także - a może głównie - między ludźmi o różnym wykształceniu, doświadczeniach życiowych, wyznaniach, statusie społecznym itd. W tym rozumieniu istotne są problemy wspomniane w niniejszym tekście.

Dotychczasowy dorobek środowisk uprawiających edukację międzykulturową zachęca do rozważenia i podjęcia pracy (prac) nad propozycjami programowymi i metodycznymi, które byłyby pomocne nauczycielom i innym zainteresowanym osobom w uwzględnianiu w kształceniu i wychowaniu ważnych problemów współczesnego świata. Może to być ważną inspiracją dla innych środowisk do tworzenia własnych programów, a przede wszystkim zachętą do spostrzegania i uwzględniania tych problemów. A - powtórzmy - są to (te i inne) podstawowe problemy, z którymi zapewne przyjdzie zmierzyć się i współczesnym, i przyszłym pokoleniom.

Idee i praktyka edukacji międzykulturowej - w ujęciu promowanym w naszym kraju - zasługują także na szersze upowszechnienie poza granicami Polski. Po części już to ma miejsce, ale przesłania edukacji międzykulturowej powinny docierać do innych społeczeństw. Trzeba działać na rzecz tej edukacji - ze świadomością, że to będzie trudny i długotrwały proces, ale z wiarą, że przynosić będzie dobre owoce.

Te trudne - wymagające pedagogicznego optymizmu i wciąż jednak poczucia edukacyjnego sprawstwa - oczekiwania mogą wśród społeczności pedagogów międzykulturowych budzić wątpliwości i pytania, dlaczego oczekiwania kierowane są właśnie do tej społeczności. Oczywiście, to powinności w ogóle wszystkich ludzi odpowiedzialnych za kształcenie i wychowanie. Szczególnymi adresatami są jednak społeczności, które mają klarowną wizję edukacji zbliżającej ludzi i otwierającej na Innych i ich kultury, społeczności mające ważne doświadczenia i dokonania. To skłania do kierowania się słowami poety: „silniejszy jestem, cięższą podajcie mi zbroję”. 


\section{Bibliografia}

Bartmiński J. (red.): Językowy obraz świata. Lublin 1990, UMCS.

Brzezińska A., Czuba T., Lutowski G., Smykowski B. (red.): Dziecko w zabawie i świecie języka. Poznań 1995, Zysk i S-ka.

Budniak J.: Miejsce dialogu ekumenicznego w środowisku wielowyznaniowym Śląska Cieszyńskiego. W: T. Lewowicki, A. Różańska, U. Klajmon-Lech (red.): Religia i edukacja międzykulturowa. Cieszyn - Warszawa - Toruń 2012, Wydział Etnologii i Nauk o Edukacji Uniwersytetu Śląskiego, Wyższa Szkoła Pedagogiczna ZNP w Warszawie, Stowarzyszenie Wspierania Edukacji Międzykulturowej, Wydawnictwo Adam Marszałek.

Chmaj M., Sokół W. (red.): Mała encyklopedia wiedzy politycznej. Toruń 1996, Wydawnictwo Adam Marszałek.

Cialdini R.: Wywieranie wptywu na ludzi - teoria i praktyka. Gdańsk 1995, GWP.

Encyklopedia popularna PWN. Warszawa 1982, PWN.

Gadamer H. G.: Prawda i metoda. Kraków 1993, Inter Esse.

Głowiński M.: Dramat języka. Uwagi o mowie publicznej IV RP. „Gazeta Wyborcza" z 25-26 listopda 2006 r.

Górecki J.: Ekumenizm w nauczaniu pastoralnym Jana Pawła II. W: J. Górecki (red.): Jan Pawet II - pasterz i pielgrzym. Katowice 2009, UŚ.

Huntington S. P.: Zderzenie cywilizacji i nowy kształt ładu światowego. Warszawa 1997, Muza.

Lewowicki T.: Przemiany oświaty. Warszawa 1994, Wydział Pedagogiczny UW.

Lewowicki T.: W poszukiwaniu modelu edukacji międzykulturowej. W: T. Lewowicki, E. Ogrodzka-Mazur, A. Szczurek-Boruta (red.): Edukacja międzykulturowa $w$ Polsce i na świecie. Katowice 2000, UŚ.

Lewowicki T., Ogrodzka-Mazur E., Szczurek-Boruta A. (red.): Edukacja międzykulturowa $w$ Polsce i na świecie. Katowice 2000, UŚ.

Lewowicki T., Różańska A., Klajmon U. (red.): Kwestie wyznaniowe w społecznościach wielokulturowych. Cieszyn 2002, UŚ - Filia w Cieszynie.

Lewowicki T.: Polityka oświatowa - od demona przeszłości, przez chaos okresu przemian ustrojowych - ku nowej polityce oświatowej. W: R. Kwiecińska, S. Kowal (red.): Edukacyjne drogi i bezdroża. Kraków 2002, AP. 
Lewowicki T.: O szkodliwości wspótczesnego języka sfery publicznej. W: T. Lewowicki: „Gorace” problemy edukacji w Polsce. Warszawa 2007, KNP PAN, Wyższa Szkoła Pedagogiczna ZNP w Warszawie.

Lewowicki T., Ogrodzka-Mazur E., Szczurek-Boruta A. (red.): Praca nauczyciela $w$ warunkach wielokulturowości - studia i doświadczenia z pogranicza polsko-czeskiego. Cieszyn - Warszawa - Toruń 2008, Wydział Etnologii i Nauk o Edukacji Uniwersytetu Śląskiego, Wyższa Szkoła Pedagogiczna ZNP w Warszawie, Wydawnictwo Adam Marszałek.

Lewowicki T.: Wielokulturowość i edukacja. „Ruch Pedagogiczny” 2010, nr 3-4.

Lewowicki T., Ogrodzka-Mazur E., Szczurek-Boruta A. (red.): Edukacja międzykulturowa - dokonania, problemy, perspektywy. Cieszyn - Warszawa Toruń 2011, Wydział Etnologii i Nauk o Edukacji Uniwersytetu Śląskiego, Wyższa Szkoła Pedagogiczna ZNP w Warszawie, Wydawnictwo Adam Marszałek.

Lewowicki T., Różańska A, Klajmon-Lech U. (red.): Religia i edukacja międzykulturowa. Cieszyn - Warszawa - Toruń 2012, Wydział Etnologii i Nauk o Edukacji Uniwersytetu Śląskiego, Wyższa Szkoła Pedagogiczna ZNP w Warszawie, Stowarzyszenie Wspierania Edukacji Międzykulturowej, Wydawnictwo Adam Marszałek.

Lewowicki T., Siemieniecki B. (red.): Cyberprzestrzeń i edukacja. Toruń 2012, Wydawnictwo Adam Marszałek.

Lewowicki T.: Edukacja międzykulturowa - bilans otwarcia 2012. „Edukacja Międzykulturowa" 2012, nr 1.

Lewowicki T.: Oświata w warunkach wielokulturowości - od asymilacji do edukacji międzykulturowej i wielowymiarowej tożsamości. W: W. G. Kremień, T. Lewowicki, J. Nikitorowicz, S. O. Sysojewa (red.): Edukacja w społeczeństwach wielokulturowych. Warszawa 2012, Wyższa Szkoła Pedagogiczna ZNP w Warszawie, Uniwersytet w Białymstoku.

Nikitorowicz J.: Koncepcja tożsamości międzykulturowej w społeczeństwie wielokulturowym. W: J. Gajda, J. Izdebska (red.): Kultura wartości ksztatcenie wobec wyzwań i zagrożeń XXI wieku. Suwałki 2004, WSSM.

Nikitorowicz J.: Edukacja regionalna i międzykulturowa. Warszawa 2009, WAiP.

Ogrodzka-Mazur E.: „Nowy nieporzadek świata” a kształtowanie (się) tożsamości globalnej. Ku pedagogice odpowiedzialności w XXI wieku. W: T. Lewowicki, E. Ogrodzka-Mazur, J. Urban (red.): Społeczne uwarunkowania 
edukacji międzykulturowej. T. 1. Konteksty teoretyczne. Cieszyn - Warszawa - Toruń 2009, Wydział Etnologii i Nauk o Edukacji Uniwersytetu Śląskiego, Wyższa Szkoła Pedagogiczna ZNP w Warszawie, Wydawnictwo Adam Marszałek.

Ogrodzka-Mazur E.: Rodzina i dziecko w otoczeniu wielokulturowym. Relacje międzypokoleniowe $i$ ich rola w przekazie wartości. W: T. Lewowicki, E. Ogrodzka-Mazur, A. Szczurek-Boruta (red.): Edukacja międzykulturowa - dokonania, problemy, perspektywy. Cieszyn - Warszawa - Toruń 2011, Wydział Etnologii i Nauk o Edukacji Uniwersytetu Śląskiego, Wyższa Szkoła Pedagogiczna ZNP w Warszawie, Wydawnictwo Adam Marszałek.

Okoń W:: Nowy stownik pedagogiczny. Warszawa, b.r.w., „Żak”.

Olbrycht K.: Rola wychowania religijnego w wychowaniu międzykulturowym. W: T. Lewowicki, A. Różańska, U. Klajmon (red.): Kwestie wyznaniowe w społecznościach wielokulturowych. Cieszyn 2002, UŚ - Filia w Cieszynie. Olbrycht K.: O roli przykładu, wzoru, autorytetu w wychowaniu osobowym. Toruń 2007, Wydawnictwo Adam Marszałek.

Patalon M.: Teologia a pedagogika: teologia mediacji H. Richarda Niebuhra jako źródło inspiracji pedagogicznych. Słupsk 2002, PAP.

Patalon M.: Pedagogika ekumenizmu: procesualność jako paradygmat interkonfesyjnej i interreligijnej hermeneutyki. Gdańsk 2007, UG.

Różańska A.: Działalność edukacyjna Ślaskiego Kościoła Ewangelickiego Augsburskiego Wyznania na Zaolziu. Cieszyn 2002, ŚKEAW.

Sadowski A.: Edukacja międzykulturowa jako nabywanie kompetencji do $\dot{z} y$ cia w społeczeństwie pluralistycznym. W: T. Lewowicki, E. Ogrodzka-Mazur (red.): Edukacja międzykulturowa - teorie, poglądy, doświadczenia społeczne. Cieszyn - Warszawa - Toruń 2010, Wydział Etnologii i Nauk o Edukacji Uniwersytetu Śląskiego, Wyższa Szkoła Pedagogiczna ZNP w Warszawie, Wydawnictwo Adam Marszałek.

Sauch P.: Suczastna oswita. Portret bez prikras. Żitomir 2012, Wid. ŻDU im. I. Franka.

Suchodolski B.: Wychowanie mimo wszystko. Warszawa 1990, WSiP.

Szczurek-Boruta A.: Wielokulturowość jako tendencja i projekcja dla edukacji (zachowania społeczne w kontekście teorii wymiany). W: T. Lewowicki, E. Ogrodzka-Mazur (red.): W poszukiwaniu teorii przydatnych w badaniach międzykulturowych. Cieszyn 2001, UŚ - Filia w Cieszynie.

Szczurek-Boruta A.: Ksztatcenie nauczycieli do wielokulturowości i międzykul- 
turowości - w kręgu potrzeb i oczekiwań. W: Z. Jasiński (red.): Szkoła i nauczyciele wobec problemów edukacji międzykulturowej. Opole 2010, UO. Walancik M., Niewiara A.: Międzykulturowość z perspektywy pontyfikatu Jana Pawta II. W: T. Lewowicki, A. Różańska, U. Klajmon-Lech (red.): Religia i edukacja międzykulturowa. Cieszyn - Warszawa - Toruń 2012, Wydział Etnologii i Nauk o Edukacji Uniwersytetu Śląskiego, Wyższa Szkoła Pedagogiczna ZNP w Warszawie, Stowarzyszenie Wspierania Edukacji Międzykulturowej, Wydawnictwo Adam Marszałek.

\section{Education in the face of eternal and contemporary world problems - contexts and challenges of intercultural education}

\section{Summary}

The modern world is plagued by many problems which raise concern for the future of societies living in different parts of our globe. These problems also affect European societies. Behaviour patterns applied by politicians are biting and in many respects harmful, the rebirth of radical nationalist and chauvinist movements takes place, religion-based conflicts do not weaken, the differences in living standards of the rich and the poor increase, there is a lot of toxic influence of mass media. What brings some help in this difficult situation is education which by definition aims at preparation for life. This duty can be fulfilled only with full regard for fundamental problems of the modern world and with attempts to understand and solve them. A particular role in this mission can and should be played by intercultural education - by inspiring and promoting undertakings which aim at the preparation for worthy and harmonious life in the multicultural world troubled by serious problems.

Key words: fundamental problems of the modern world, education, disfunctionality of education, intercultural education, educational challenges 